Supporting Information

For

\title{
Photoregulation of a Peptide-RNA Interaction on a Gold Surface
}

Gosuke Hayashi, Masaki Hagihara, Chikara Dohno, and Kazuhiko Nakatani

Department of Regulatory Bioorganic Chemistry, The Institute of Scientific and Industrial Research, Osaka University, 8-1 Mihogaoka, Ibaraki 567-0047, Japan.

\section{Supporting Information}

The contents of supporting information include:

$\begin{array}{ll}\text { 1) Experimental procedures } & \text { PageS2 }\end{array}$

2) Stability of Z-KRAzR in the dark (Figure S1) PageS6

3) Monitoring the enrichment of RNA binding to KRAzR by SPR assay (Figure S2)

PageS7

4) Sequences of RNA aptamers (Table S1)

PageS8

5) SPR analysis for the Binding of RNA aptamers to KRAzR (Figure S3)

PageS9

6) The binding of Apt19 to KRAzR with competitive peptides (Figure S4)

7) Photoregulation of the binding of KRAzR to Apt23 and Apt 40 on Gold Surface (Figure S5)

PageS11

8) CD spectra of Apt19 in the absence and presence of KRAzR PageS12

9) Synthesis of KRAzR-PEO PageS13

10) SPR imager equipped with a handmade cell holder having photoirradiation window

PageS14

11) Real-time monitoring of photoresponsive binding of Apt 19 to

KRAzR-immobilized surface by SPR imaging 


\section{1) Experimental procedure}

\section{Synthesis of KRAzR}

Standard fluorenylmethoxycarbonyl(Fmoc)-based solid phase peptide synthesis method was used to prepare Lys-Arg-(4-aminomethyl)phenylazobenzoicacid-Arg. Peptides were synthesized on Fmoc-Arg(Pbf)-Alko resin (Wang resin) (Watanabe Chemical Industries). The syntheses were performed manually using the following amino acid derivatives: Fmoc-Azobenzene-OH, Fmoc-Arg(Pbf)-OH, Fmoc-Lys(Boc)-OH. Coupling reactions used 3 equivalents of Fmoc-amino acid derivatives, 3 equivalents of 1-hydroxybenzotriazole $(\mathrm{HOBt}), 3$ equivalents of 2-(1H-benzotriazol-1-yl)-1,1,3,3-tetramethyluronium hexafluorophosphate (HBTU), and 6 equiv. of $N, N$-diisopropylethylamine (DIPEA). Deprotection of Fmoc group was done by $20 \%$ piperidine for 20 minutes. For all coupling, washing, and deprotection steps, DMF was used as solvent. Coupling efficiency was monitored by the Kaiser test. Peptide cleavage from the resin was carried out with the cocktail of $95 \%$ trifluoroacetic acid (TFA) and 5\% distilled water, for 2 hours. The crude products were precipitated with ether and then purified by HPLC [COSMOSIL 5C 18 -MS-II column (Nacalai Tesque) using a linear gradient from 0 to $30 \%$ acetonitrile $/ \mathrm{H}_{2} \mathrm{O}$ (containing $0.1 \%$ TFA) over 30-min elution]. The peptide was identified by ESI-MS measurements. ESI-MS $\mathrm{C}_{32} \mathrm{H}_{49} \mathrm{O}_{13} \mathrm{~N}_{5}$ : calcd. 695.40; obs. 696.38 $[\mathrm{M}+\mathrm{H}]^{+}$

\section{Photoisomerization and UV/Vis Spectra}

Photoisomerization of KRAzR was accomplished by irradiating the peptide solutions with a LAX-102 xenon lamp (Asahi Spectra) coupled to a high intensity monochromator through 360- or 430-nm bandpass filter for $5 \mathrm{~min}$.

UV/Vis spectra were recorded by DU800 UV/Visible Spectrophotometer (Beckman Coulter) using a $1-\mathrm{cm}$ quartz cell in a thermostated holder. The measuring beam was found to have a negligible effect on the isomerization of $E$ or $Z-\mathbf{K R A z R}$.

\section{Derivatization of resin for in vitro selection}

KRAzR was coupled to Affi-gel 10 (Bio-Rad) according to the manufacturer's instructions. The resin was prepared with $5.0 \mu \mathrm{M}$ ligand per milliliter of agarose (5.0 $\mathrm{mM})$. For preselection, a glycine-drivatized agarose $(10.0 \mathrm{mM})$ was used. 


\section{Preparation of RNA pools}

For the starting selection on KRAzR, a 131-mer synthetic oligonucleotide (5'GCTAATACGACTCACTATAGGGAATTCCGCGTGTGCACACC(N $\left.{ }_{70}\right)$ GTCCGTTC GGATCCTCATGG-3') that contained a T7 RNA polymerase promoter (underlined), a 70-nt random region and recognition sites of restriction enzymes, EcoRI and BamHI, respectively (shown in a bold face) was purchased from Japan Bio-Service Inc.. A $70 \mu \mathrm{g}$ of DNA was PCR-amplified in a total volume of $8.0 \mathrm{~mL}$ in 80 tubes containing $100 \mu \mathrm{l}$ of PCR-mix ( $1 \mu \mathrm{M}$ of forward and reverse primers; dNTP mix; Taq polymerase) for 4 cycles (temperature cycle conditions: $98{ }^{\circ} \mathrm{C}, 10 \mathrm{sec} ; 55^{\circ} \mathrm{C}, 30 \mathrm{sec} ; 72{ }^{\circ} \mathrm{C}, 30 \mathrm{sec}$ ). After isopropanol precipitation, $170 \mu \mathrm{g}$ of amplified DNA was used in a $2.7 \mathrm{~mL}$ transcription reaction in 27 tubes, each containing $100 \mu \mathrm{L}$ of transcription mix and transcribed at $37{ }^{\circ} \mathrm{C}$ for 6 hours. DNase I was added and incubation was continued for $30 \mathrm{~min}$. The RNA was purified by gel filtration by NAP 10 column (Amersham Biosciences).

\section{In vitro Selections against KRAzR-agarose}

To minimize the enrichment of RNA molecules that bind to the parts of the agarose and the spacer, the pool was preselected on glycine-derivatized agarose. Agarose for the selection was equilibrated with several column volumes of binding buffer $(250 \mathrm{mM}$ $\mathrm{NaCl} ; 50 \mathrm{mM}$ Tris- $\mathrm{HCl}, \mathrm{pH}=8.0 ; 5 \mathrm{mM} \mathrm{MgCl}_{2}$ ). A $500 \mu \mathrm{L}$ sample of the RNA pool (550 $\mu \mathrm{g})$ in binding buffer was loaded onto the preselection column. The preselection column was rinsed with $1.0 \mathrm{~mL}$ of binding buffer, and the eluting RNA was directly applied onto the selection column. This column was rinsed with $500 \mu \mathrm{L}$ and then with 4 $\mathrm{mL}$ of a binding buffer. The flow through was discarded. Elution of aptamers was done with $3.0 \mathrm{~mL}$ of a $6.0 \mathrm{mM}$ solution of KRAzR in a binding buffer. The eluted RNA was purified by isopropanol precipitation and reverse-transcribed at $42^{\circ} \mathrm{C}$ for $30 \mathrm{~min}$ by reverse transcriptase. The resulting cDNA was PCR-amplified by Taq polymerase, purified, and transcribed. The purified RNA was used as the input for the next selection cycle.

\section{Binding study of aptamers to KRAzR by SPR assay}

SPR measurements were carried out at $25^{\circ} \mathrm{C}$ using BIACORE 2000 (BIAcore). 
Photoresponsive peptide KRAzR was immobilized onto the CM5 sensor chip (BIAcore) covered with NHS-activated carboxylic acid. After purification by PAGE ( $8 \%$ acryl amide, $200 \mathrm{~V}, 30 \mathrm{~min}$ ), transcribed RNA samples were dissolved in a running buffer $\left(250 \mathrm{mM} \mathrm{NaCl} ; 50 \mathrm{mM}\right.$ Tris-HCl, $\left.\mathrm{pH}=8.0 ; 5 \mathrm{mM} \mathrm{MgCl}_{2}\right)$ and analyzed by SPR at concentration from 0.5 to $2.0 \mu \mathrm{M}$ with Kinject command defining an association time of $120 \mathrm{~s}$ and a dissociation time of $120 \mathrm{~s}$. In each measurement, bound RNA was washed out by $10 \mathrm{mM} \mathrm{NaOH}$. For determining the $\mathrm{Kd}$ values, the fitting algorithm of Langmuir 1:1 stoichiometry was used. Peptides (KR, KRR, KRGR, KRGGR, KRGGGR) were purchased from SCRUM for competitor assays. Azobenzene amino acid was synthesized. Competitor peptide was mixed with Apt19 solution and analyzed with the KRAzR-immobilized sensor. Photoisomerization of KRAzR on gold surface was done by irradiation of 360 or $430 \mathrm{~nm}$ light to the peptide surface through the droplet of a running buffer.

\section{Synthesis of KRAzR-PEO}

Colorless oil of poly (ethylene oxide) (PEO) linker (7.8 mg, $16.5 \mu \mathrm{mol})$ was dissolved in $500 \mu \mathrm{l}$ of $\mathrm{MeOH}$. To $1 \mathrm{~mL}$ of $5 \mathrm{mM}$ KRAzR in reaction buffer $(0.2 \mathrm{M} \mathrm{NaHCO} 3$ and $0.5 \mathrm{M} \mathrm{NaCl}$ ) was added $200 \mu \mathrm{l}$ of the PEO linker solution and stirred at room temperature for 5 hours. The reaction was monitored by HPLC. The reaction mixture was purified by HPLC (water/acetonitrile containing $0.1 \%$ TFA). The isolated compound (KRAzR-PEO-Boc) was identified by ESI-TOF MS. Aqueous hydrochloric acid $(4 \mathrm{M}, 500 \mu \mathrm{l})$ was added to the eluate for deprotection of Boc group. After the reaction completed, the sample was evaporated. The residue was dissolved in water and concentration of the solution was determined by UV absorbance.

\section{Fabrication of SPR imaging array}

A gold-coated chip (SPR-200) for SPR imaging analysis was purchased from TOYOBO (JAPAN). A $5 \mathrm{ml}$ of $1 \mathrm{mM}$ PEG6-COOH alkanethiol (TOYOBO, SPT-0012A) in ethanol was added onto the gold surface and reacted for more than 7 hours. After washed with ethanol and distilled water, the $\mathrm{COOH}$-modified surface was reacted for 30 minutes with $200 \mu \mathrm{L}$ of EDCI/NHS solution to create a NHS-activated surface. The 10 $\mathrm{nL}$ drops of 1 or $0.5 \mathrm{mM}$ KRAzR-PEO in reaction buffer $(0.2 \mathrm{M} \mathrm{NaHCO} 3$ and $0.5 \mathrm{M}$ $\mathrm{NaCl}$ ) were delivered automatically on the NHS-activated $\mathrm{COOH}$ surface using an 
automated spotter (TOYOBO). The amide coupling was left reacted for 5 hours. A 200 $\mu \mathrm{L}$ of $100 \mathrm{mM}$ ethanolamine was further reacted on the array surface for 1 hours to block the remained NHS group. The array surface was rinsed with $500 \mathrm{mM} \mathrm{KCl}, 10$ $\mathrm{mM} \mathrm{NaOH}$ and water.

\section{SPR imaging analysis}

The KRAzR-PEO immobilized SPR array was placed in the SPR imaging instrument (SPR-101, TOYOBO, Japan). After washing the surface with $50 \mathrm{mM} \mathrm{NaOH}$ for $5 \mathrm{~min}$, running buffer (binding buffer used in in vitro selection) was applied onto the array for 1 minute. RNA aptamer $(10 \mu \mathrm{M}, 200 \mu \mathrm{L})$ in the running buffer were applied with a flow speed of $100 \mu \mathrm{l} / \mathrm{min}$. The flow was stopped after the whole sample was injected. Then $360 \mathrm{~nm}$ light was directly irradiated to the surface for 5 minutes and continuously 430 $\mathrm{nm}$ light was irradiated for 5 minutes. For control experiment, a series of irradiation were performed without RNA aptamer. All SPR experiments were performed at room temperature. The SPR array was reused after washing with $50 \mathrm{mM} \mathrm{NaOH}$ for $3 \mathrm{~min}$. The SPR images and signal data were collected with MultiSPRinter Analysis program (TOYOBO). 
2) Stability of $Z$-KRAzR in the dark

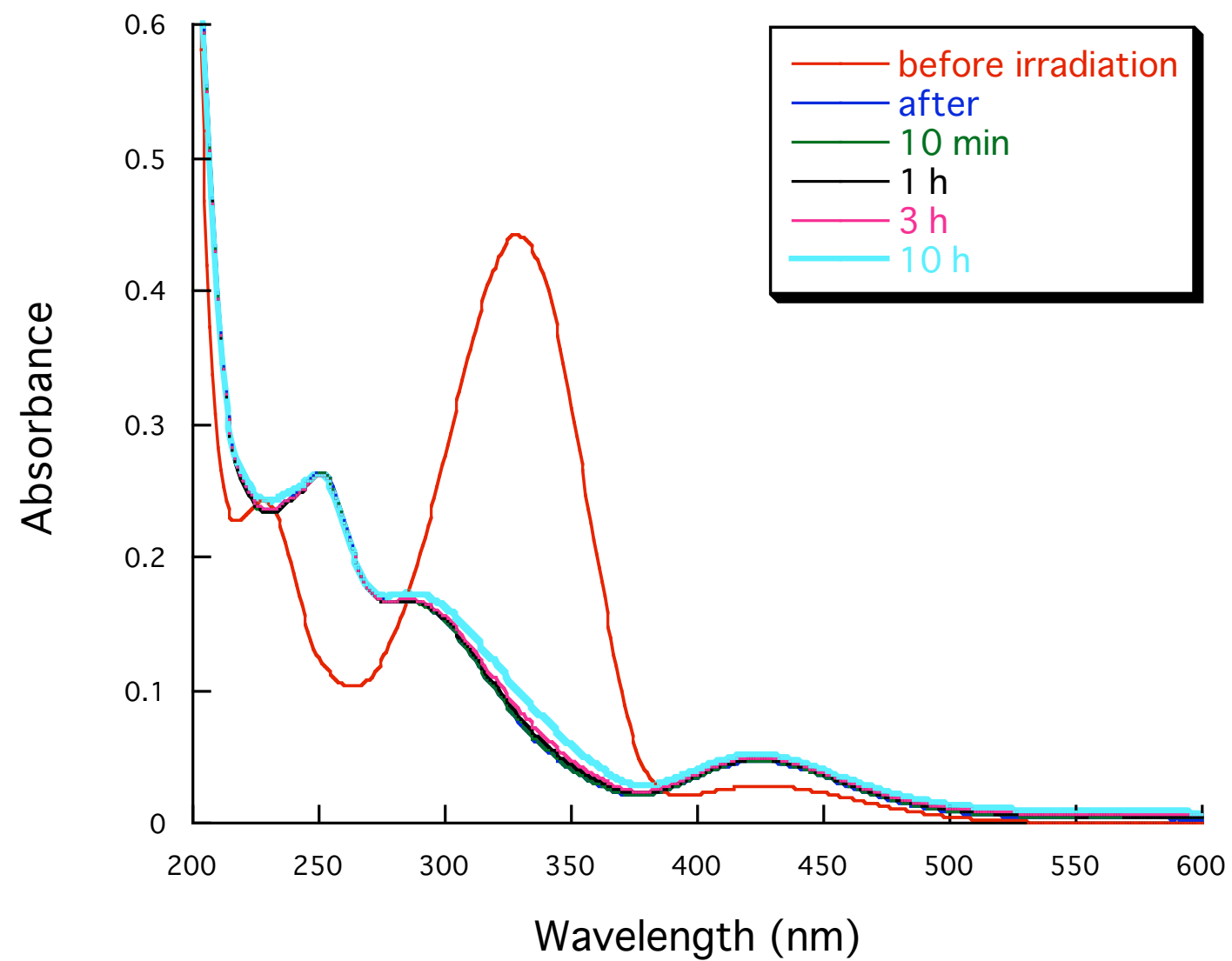

Figure S1. UV-Vis spectra of Z-KRAzR before and after photoirradiation at $360 \mathrm{~nm}$. UV-Vis spectra of the $20 \mu \mathrm{M}$ solution of KRAzR in water was measured before and after irradiation of $360 \mathrm{~nm}$ light for 0 , $10,60,180$ and $6000 \mathrm{~min}$ in the dark. 
3) Monitoring the enrichment of RNA binding to KRAzR by SPR assay

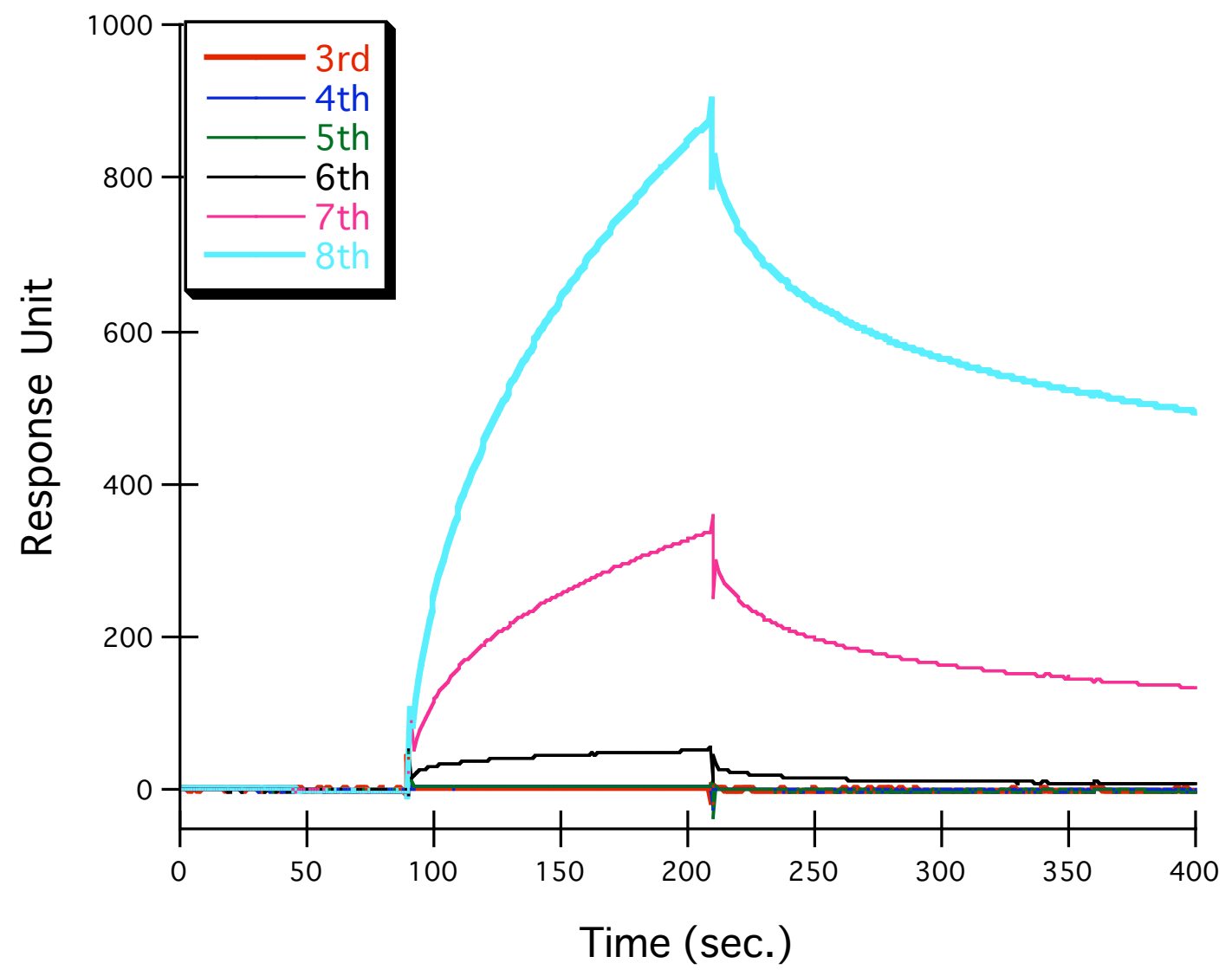

Figure S2. SPR sensorgram for the binding of RNA pool to KRAzR-immobilized surface after each selection round. The concentration of RNA pool was adjusted to $2.0 \mu \mathrm{M}$. Running buffer contains 50 $\mathrm{mM}$ Tris- $\mathrm{HCl}$ (pH 8.0), $250 \mathrm{mM} \mathrm{NaCl}$, and $5 \mathrm{mM} \mathrm{MgCl}_{2}$. 
4) Sequences of RNA aptamers

Table S1. Sequence of RNA aptamers.

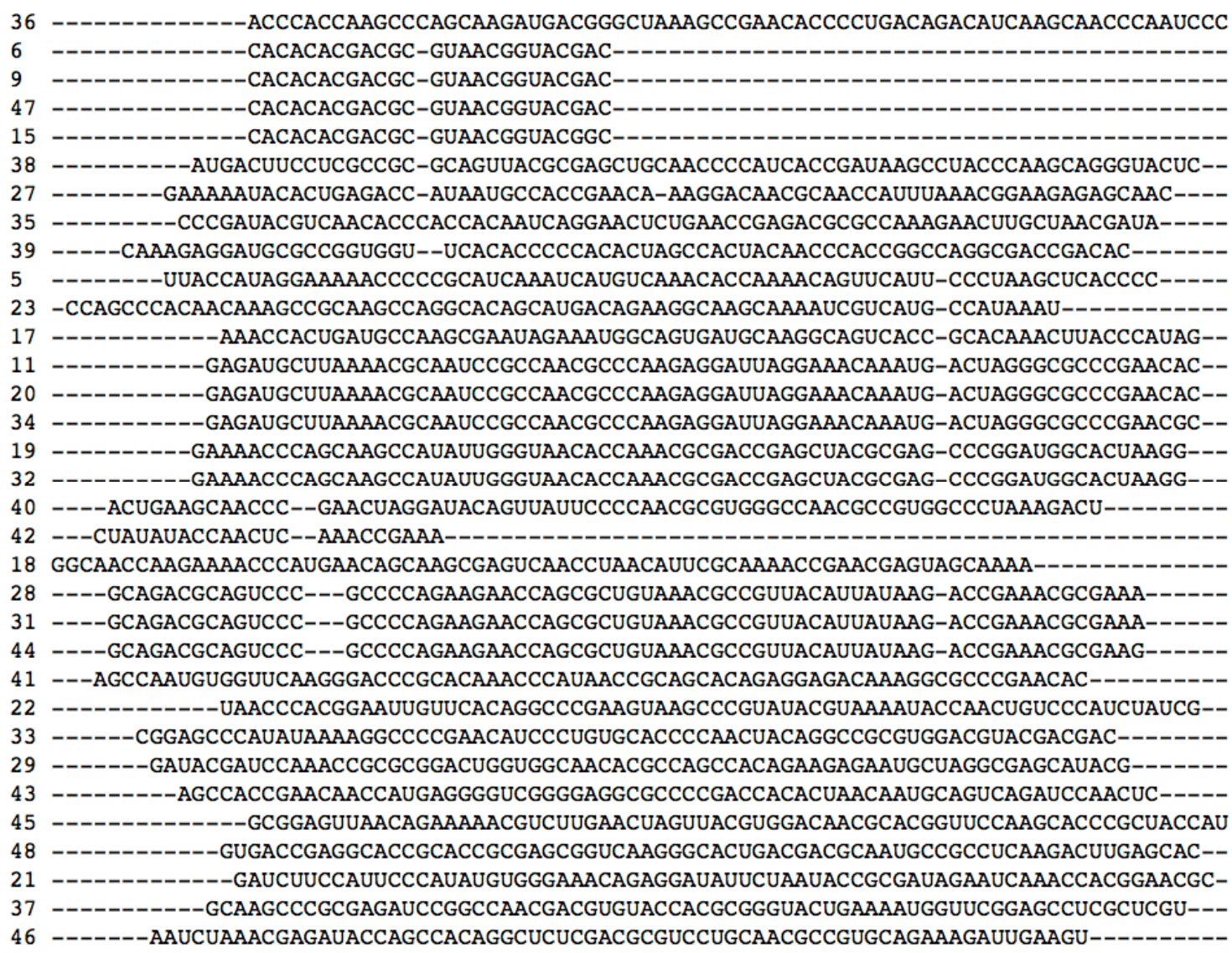

Multiple sequence alignment was done by software CLUSTALW (http://align.genome.jp/) 


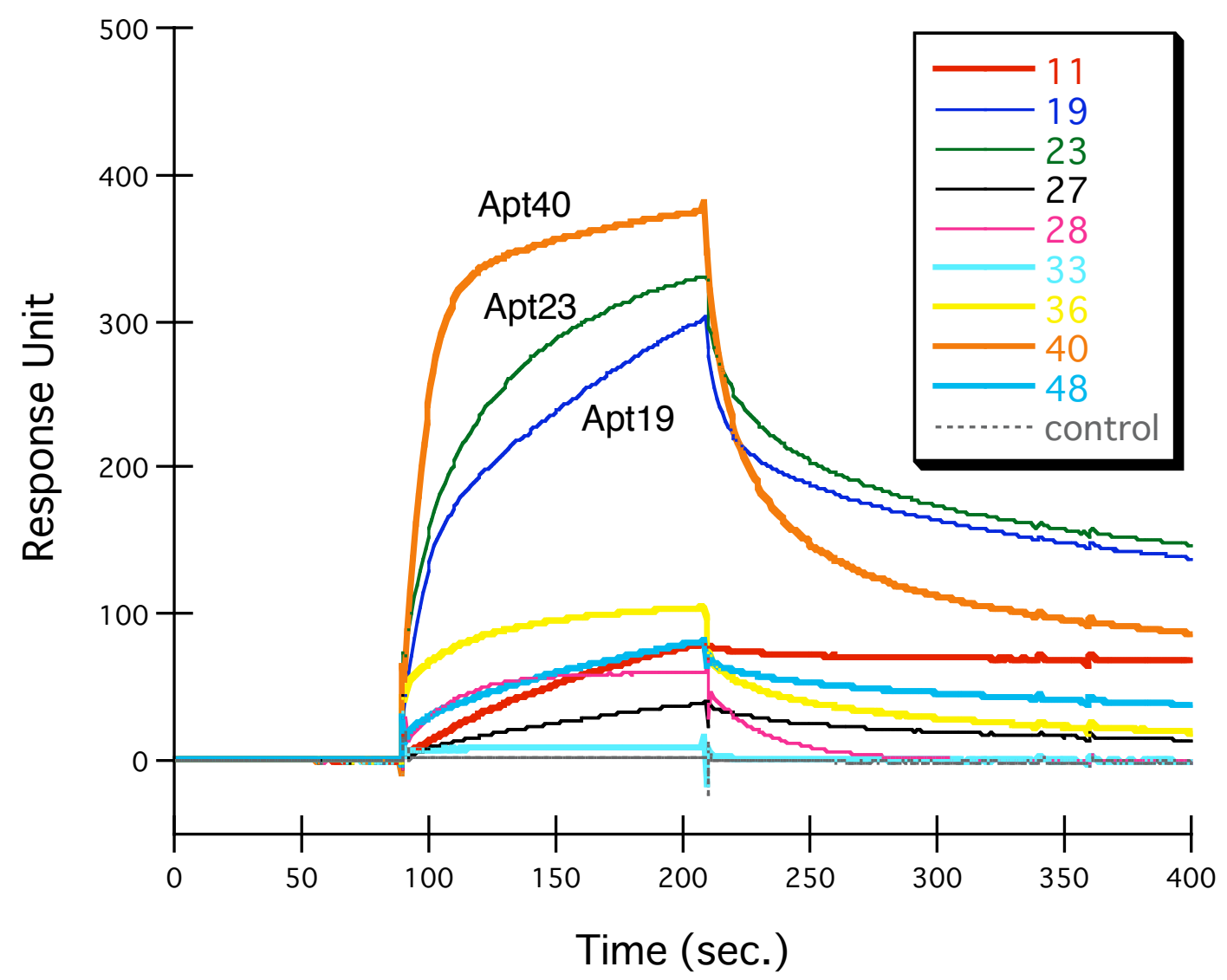

Figure S3. The binding of isolated aptamers to KRAzR-immobilized surface. The concentration of each RNA aptamer was adjusted to $0.5 \mu \mathrm{M}$. Running buffer contains $50 \mathrm{mM}$ Tris- $\mathrm{HCl}$ (pH 8.0), $250 \mathrm{mM} \mathrm{NaCl}$, and $5 \mathrm{mM} \mathrm{MgCl}_{2}$. As a negative control, RNA pool obtained after 1st round selection was used. 
6) The Apt19 binding to KRAzR with competitive peptides
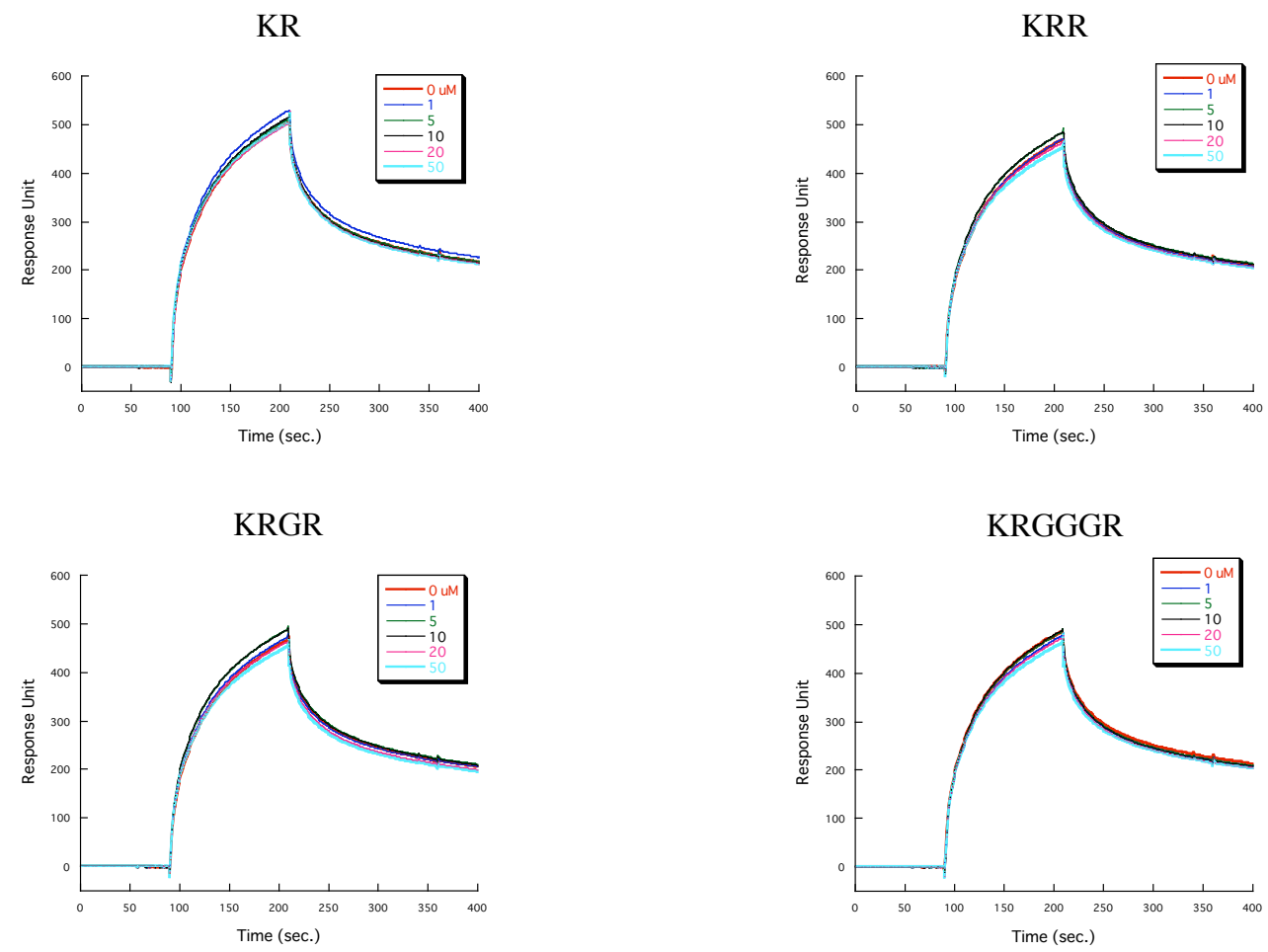

Arginine

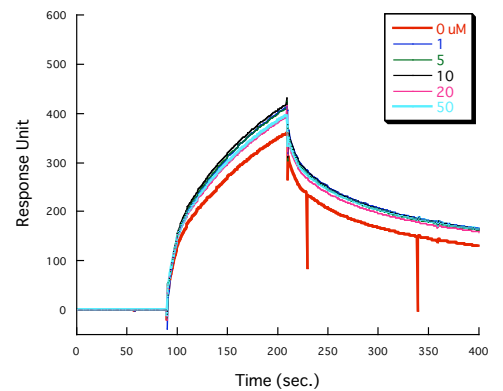

Azobenzene amino acid

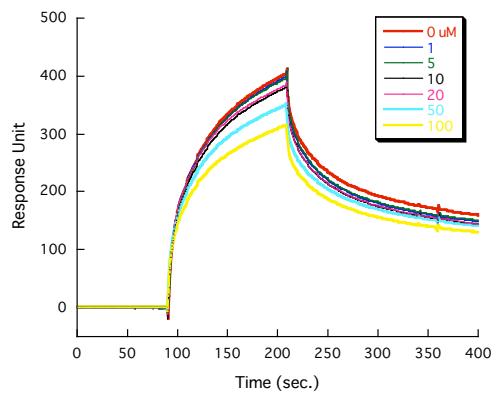

$\mathrm{K}^{\mathrm{Ac}} \mathrm{RAzR}$
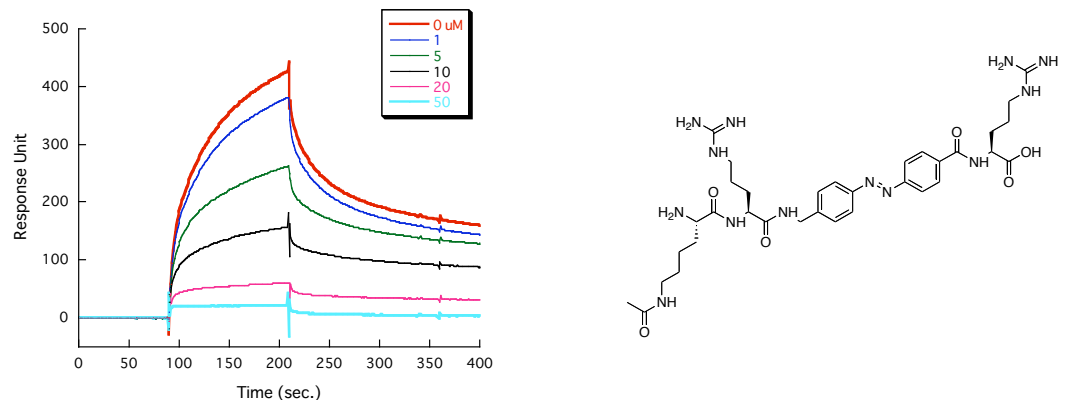

Figure S4. SPR assay of the Apt19 binding to KRAzR-immobilized surface in the presence of competitor peptides. The concentration of Apt19 was $1.0 \mu \mathrm{M}$. Running buffer contains $50 \mathrm{mM}$ Tris- $\mathrm{HCl}(\mathrm{pH} 8.0)$, $250 \mathrm{mM} \mathrm{NaCl}$, and $5 \mathrm{mM} \mathrm{MgCl}_{2}$. The competitor concentration was $0,3,5,10,20$, and $50 \mu \mathrm{M}$. 
7) Photoregulation of peptide-RNA binding on Gold Surface

a)

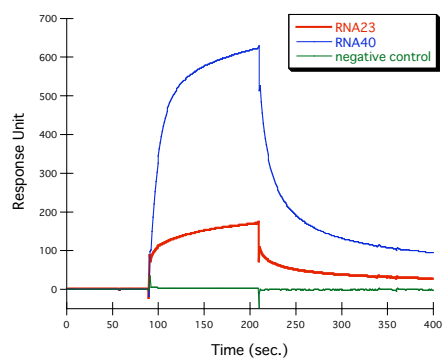

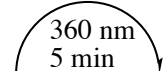

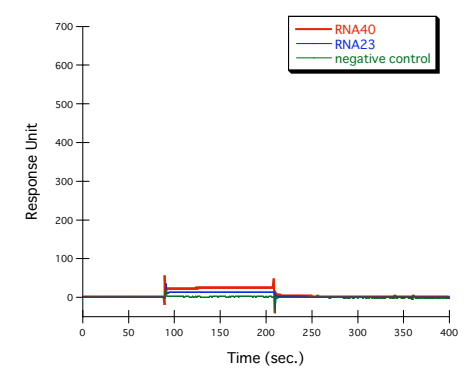

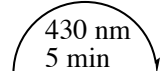

c)

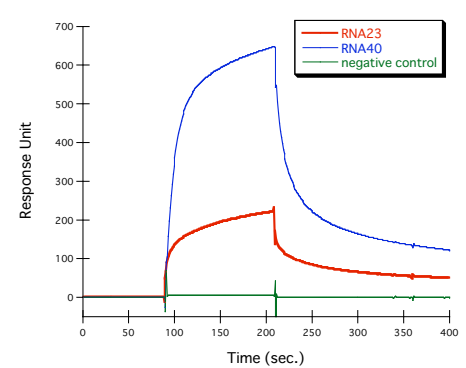

Figure S5. The binding of Apt 23 (red line) and Apt 30 (blue line) was analyzed with KRAzR-immobilized SPR sensor. a) left under room light, b) after photoirradiation of $360 \mathrm{~nm}$ light for $5 \mathrm{~min}$, and c) subsequent photoirradiation of $430 \mathrm{~nm}$ light for $5 \mathrm{~min}$. The concentration of each RNA aptamer was adjusted to $1.0 \mu \mathrm{M}$. Running buffer contains $50 \mathrm{mM}$ Tris- $\mathrm{HCl}$ (pH 8.0), $250 \mathrm{mM} \mathrm{NaCl}$, and $5 \mathrm{mM} \mathrm{MgCl}$. 
8) CD spectra of Apt19 in the absence and presence of KRAzR

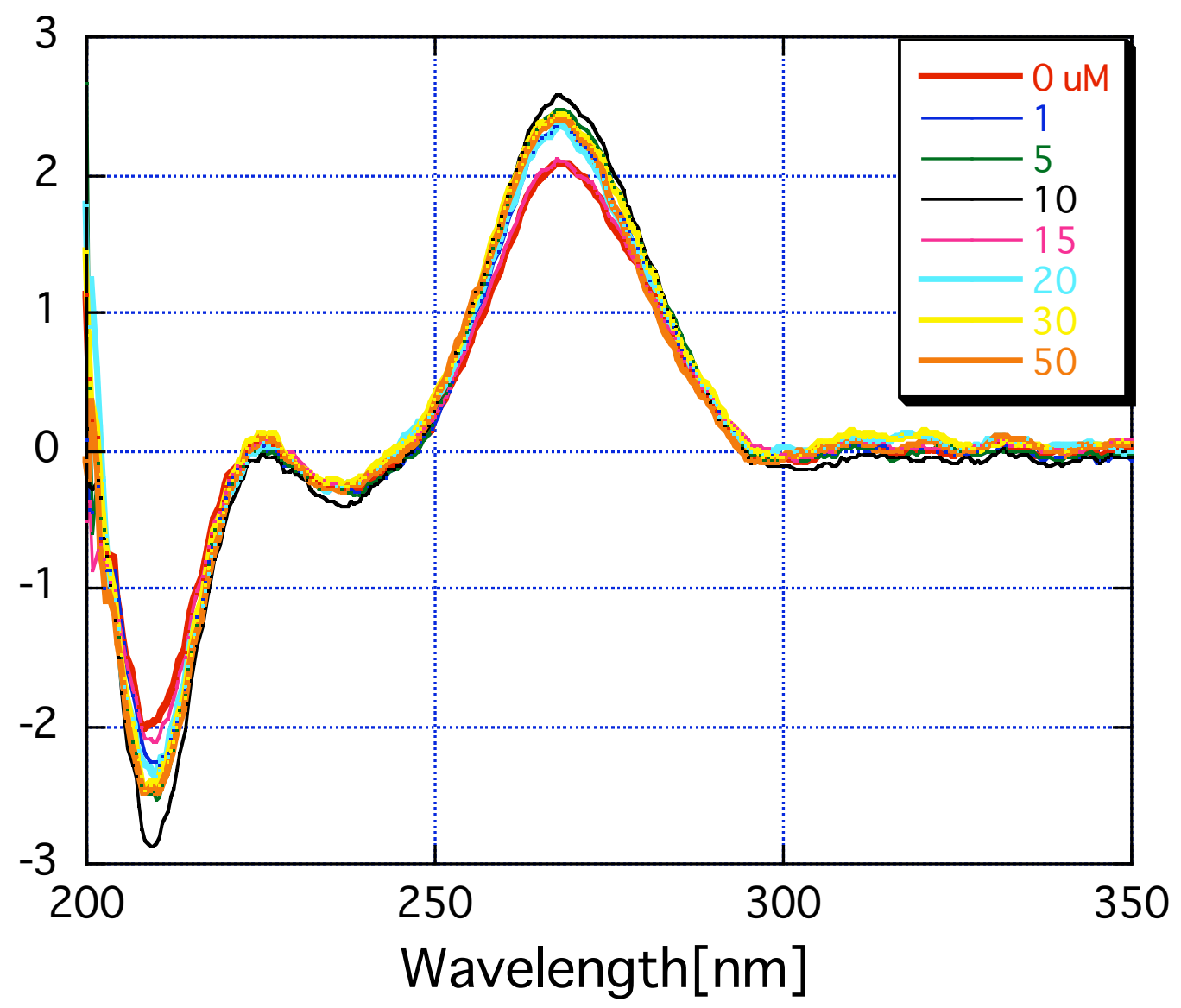

Figure S6. CD spectra of Apt19 in the absence and presence of KRAzR. The concentration of Apt19 was $1.0 \mu \mathrm{M}$. The sample solution contains $50 \mathrm{mM}$ Tris- $\mathrm{HCl}(\mathrm{pH}$ 8.0), $250 \mathrm{mM} \mathrm{NaCl}$ and $5 \mathrm{mM} \mathrm{MgCl2}$. Sample volume was $300 \mu \mathrm{l}$. The concentration of KRAzR was $0,1,5,10,15,20,30$, and $50 \mu \mathrm{M}$. 
9) Synthesis of KRAzR-PEO

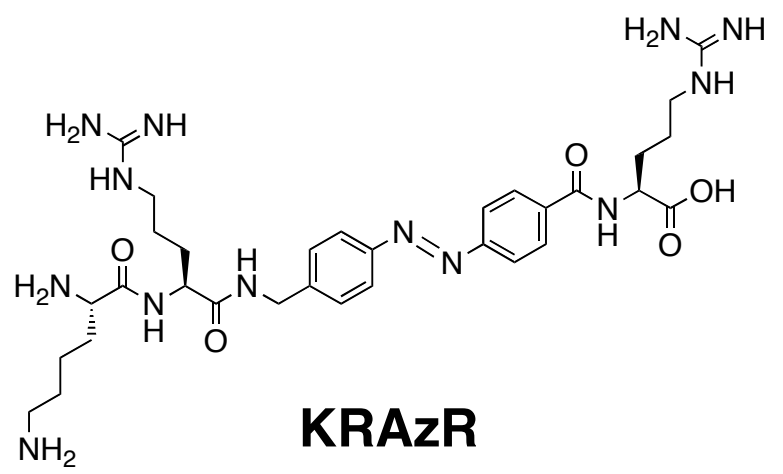

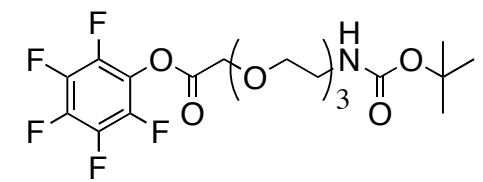

PEO-linker

$0.2 \mathrm{M} \mathrm{NaHCO}_{3}$,

$0.5 \mathrm{M} \mathrm{NaCl}$ buffer/MeOH

$\stackrel{\mathrm{aq} . \mathrm{HCl}}{\longrightarrow}$<smiles>N=C(N)NCCCC(NC(=O)[C@@H](N)CCCCNC(=O)COCCOCCOCCN)C(=O)NCc1ccc(N=Nc2ccc(C(=O)N[C@@H](CCCNC(N)N)C(=O)O)cc2)cc1</smiles>

KRAzR-PEO

Scheme S1. Synthesis of KRAzR-PEO 
10) SPR imager equipped with a handmade cell holder having photoirradiation window.

a)

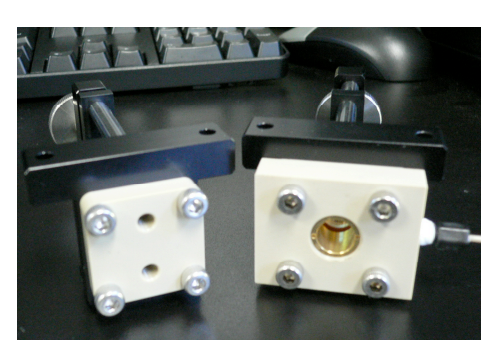

b)

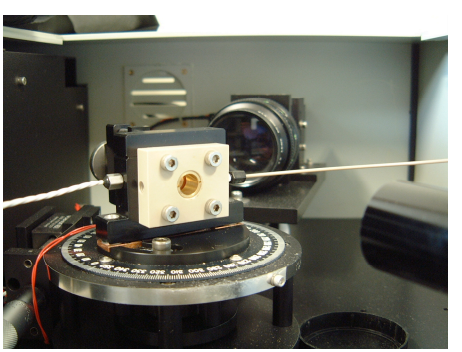

c)

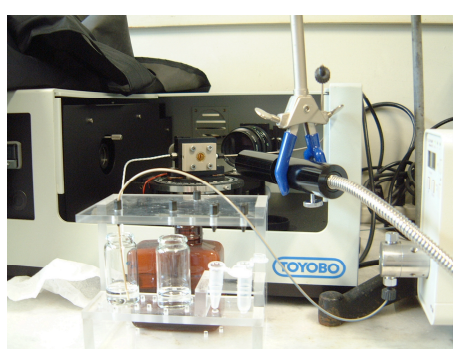

Figure S7 a) Close up of the handmade cell holder having a photoirradiation window (right) and the original cell holder (left), b) and c) alignment of cell, CCD camera, and a photoirradiation device that can irradiate the cell at 360 and $430 \mathrm{~nm}$ light. 
11) Real-time monitoring of photoresponsive binding of Apt19 to KRAzR-immobilized surface by SPR imaging.

(a)

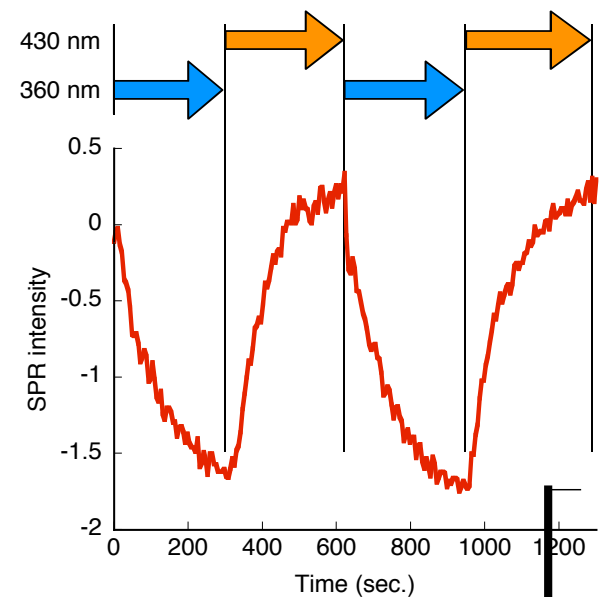

(b)

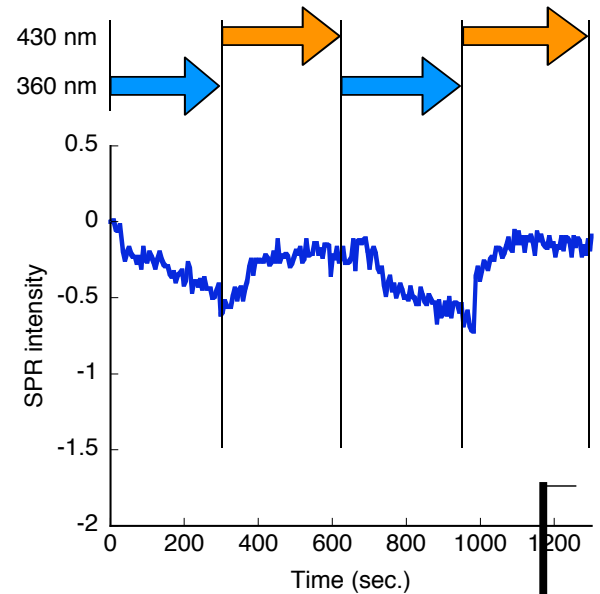

Figure S8. Real-time monitoring of photoresponsive binding of Apt19 to KRAzRimmobilized surface by SPR imaging. a) SPR sensorgram obtained by irradiating the Apt19-bound KRAzR surface alternatively with $360 \mathrm{~nm}$ and $430 \mathrm{~nm}$ for $5 \mathrm{~min}$. Apt 19 was bound to the KRAzR-immobilized gold surface by flowing the Apt19 solution on the surface. Having completed the Apt19 binding to the surface by confirming the saturation of the binding curve, the flow of the RNA solution was stopped (time $=0 \mathrm{sec}$ ). The Apt19-bound KRAzR surface was irradiated at $360 \mathrm{~nm}$ for $5 \mathrm{mim}$. The SPR intensity was decreased as the photoirradiation. Then, the surface was irradiated at 430 $\mathrm{nm}$ for $5 \mathrm{~min}$. The SPR intensity increased as the photoirradiation. The photoirradiation cycle was repeated with good signal reproducibility. c) SPR response of the KRAzRimmobilized gold surface in the absence of Apt19. Upon photoirradiation, small change in the SPR intensity was observed due to the photoisomerization of the KRAzR immobilized on the gold surface. The difference in the SPR intensity between a) and b) is due to the presence and absence of Apt19, showing that Apt19 bound to E-KRAzR dissociated from the surface upon photoisomerization of $E$-KRAzR to Z-KRAzR. 